\title{
Changes after voice therapy in objective and subjective voice measurements of pediatric patients with vocal nodules
}

Ciler Zahide Tezcaner • Selmin Karatayli Ozgursoy • Isil Sati · Gursel Dursun

Published online: 1 August 2009

(C) Springer-Verlag 2009

Erratum to: Eur Arch Otorhinolaryngol

DOI 10.1007/s00405-009-1008-6

The second author's name was rendered wrongly. The correct name is Selmin Karatayli Ozgursoy.

The online version of the original article can be found under doi: 10.1007/s00405-009-1008-6.

C. Z. Tezcaner · S. Karatayli Ozgursoy · I. Sati · G. Dursun Department of Otorhinolaryngology, Ankara University School of Medicine, Ankara, Turkey

C. Z. Tezcaner $(\square)$

Bardacık Sok. 79/2 Küçükesat, Ankara, Turkey

e-mail: cbuyukatalay@yahoo.com 